\title{
13 Stakeholder Management in the Hong Kong Construction Industry
}

\author{
Steve Rowlinson, Tas Yong Koh and Martin Morgan Tuuli
}

\subsection{Introduction}

Hong Kong is world renowned for its impressive infrastructure, such as the airport at Chek Lap Kok, and famous buildings, such as the Hongkong Bank building and 2IFC, for the pace of the construction process and for the quality of the finished product. The construction industry is lauded for its 'can-do' attitude and the apparently high levels of integration and cooperation that enable its high level of performance. One might well imagine that an industry that can regularly complete 4-day floor cycles on high rise buildings over 40 storeys would be an innovative and relationship-based industry. However, this is not the case. For example, the predominant form of procurement in Hong Kong is still design-bid-build (the 'traditional' approach) and 'partnering' has been introduced into the industry but in a piecemeal fashion and in a manner which is hardly effective (Rowlinson and Cheung, 2008).

The historical context of the industry is important in understanding the current situation in Hong Kong. Hong Kong 'returned' to China after 150 years of British colonial rule in 1997. During these 150 years, a 'British' approach to construction was followed which focused strongly on the traditional approach and was regulated and administered by a strong civil service. This led to an industry which relied heavily on hierarchy, tradition and procedures in order to function effectively, but the industry was also heavily influenced by the Chinese culture in which it was situated. Hence, values such as face, harmony and conflict avoidance were also embedded in the industry culture. In such a situation, the issue of stakeholders and their management was paid scant regard; the government was used to making decisions on development rather than consulting widely and the other major players, the oligarchy of large property developers, adopted a simple, economic approach to their business plans and only over the past few years have issues such as corporate social responsibility (CSR) reached their boardrooms.

In this context, stakeholder management and relationship management can be said to be in their infancy and in some ways run counter to the ethos and philosophy of an industry where speed and money are king. However, Hong Kong people have become much more demanding of their government and institutions and have demanded that they be consulted and involved in all major and minor developments (e.g. the West Kowloon Cultural Hub, the Tamar Site Redevelopment, the demolition of the Star Ferry and Queen's Piers). Indeed, during the Handover period, Hong Kong people took to the streets demanding freedom and democracy and those demands continue to this day as political reform has come slowly to the colonial and post-colonial systems.

Having briefly set the scene, we present below two case studies, one a civil engineering project and the other a public housing project, which draw out a number of the themes 
alluded to above by way of example. We then attempt to draw together some generalisations on how stakeholder and relationship managements are enacted in Hong Kong, identifying drivers and inhibitors to their successful implementation, and noting the impact of history, tradition and culture on how they are implemented and used in Hong Kong. We conclude with the assertion that stakeholder management and relationship management must be implemented in a context-specific manner in each instance and that a 'PMBOK' recipe style approach to these issues will not be effective nor efficient.

\subsection{Stakeholder management initiatives}

Project stakeholders are a person or group of people who have a vested interest in the success or failure of a project and the environment within which the project operates (Olander, 2007, p. 278). Vested interest, in turn, can be viewed as the actual or perceived benefits or risks / harms from the activities of construction project management (Donaldson and Preston, 1995). The project stakeholders may have a positive or a negative influence on the project. The challenge for the project team, hence, becomes one of implementing the project strategies such that positive stakeholder's influence is maximised and negative influence is minimised (Walker et al., 2008). In analysing stakeholder management activities, it is useful to categorise stakeholders into two broad groups: primary and secondary stakeholders. Primary stakeholders are people or groups that have a legal contractual relationship to the project. Secondary stakeholders, on the other hand, are those who influence or are influenced by the project but are otherwise not regularly engaged in transactions with the project (Cleland and Ireland, 2007, p. 151). It is apparent that the client, the main and subcontractors, the quantity surveyor, suppliers and the like belong to the former group, while local communities and general public the latter.

\subsubsection{Background}

The Hong Kong Special Administrative Region (HKSAR) government has embraced the worldwide trend of sustainable development. Consequently, in the development front, the HKSAR government has emphasised sustainability and community development in procuring and implementing construction projects. Four sustainability dimensions have been adopted by the government when administering construction projects. These dimensions focus on economics, environment, society and resource utilisation. The client of the project in case study A implemented the four dimensions in all aspects of the procurement and the administration of the project. The thrust is based on sustainable construction, the aim of which is to progressively achieve sustainable development in public housing. The efforts are that of balancing the economic, social and environmental concerns of all the stakeholders in the project. To achieve these goals, various issues are embedded in the tendering and contracting procedures in the implementation of the project.

\subsection{Project description - Case A}

Bearing in mind the foregoing discussion, we now describe the context of project $\mathrm{A}$. The economic dimension focuses on attainment of cost effectiveness of the project. Cost effectiveness is critical for economic sustainability because all aspects of the housing development, construction, through to operation and maintenance impact on the budget. Public funds are at stake. 
The environmental dimension concerns the maintenance or betterment of the environment where the development is located. Construction activities have to be undertaken such that the impacts to the surrounding residents and community are kept to a minimum. Better construction methods and the use of more environmentally friendly construction materials are two strategies to achieve these objectives. Resource utilisation is related to the environmental dimension. The main thrust is to properly manage and reduce the consumption of resources in the construction processes. The production of waste and the use of energy are the two main areas of concerns. The social dimension is grounded in the client's belief that public housing and its development and construction have to promote social stability, economic prosperity and foster social cohesion. In the construction of the project, the client strives to provide a model working environment for those working on the site. As will become apparent, these dimensions are variously manifested in the procurement and stakeholder management of the project.

The project presented is one government project administered under such a backdrop. The project involves the construction of a public rental housing estate. Three 41-storey blocks are to be built. Each block measures approximately $50 \times 34 \mathrm{~m}$ on plan. The blocks are approximately $117 \mathrm{~m}$ high from the ground floor to the main roof level. The three blocks consist of over 2300 rental domestic flat units of various types and sizes. Apart from these building works, there are also some civil engineering works. These works include excavation, filling, disposal, lateral support works for the raft foundations, and pilecap works for the three domestic blocks.

In addition, there are other structures that are incorporated in the project. The housing estate will be served by a neighbourhood elderly centre. The works involve the construction and fitting out of the centre. A bus terminus is to be built next to the estate. The works for the bus terminus include site formation, construction, backfilling, drainage works, street furniture and the associated services works. A two-storey lift tower with an attached footbridge connecting the estate to the adjacent residential areas and commercial centre are to be constructed. The pile foundations of these facilities are also included in the construction of these facilities. A double-deck walkway will be constructed to connect the current estate to the next estate. Finally, there is the construction of auxiliary structures. These include drainage and external works, slope improvement works, retaining walls, permanent protection to the existing gas offtake station, and road works within the estate.

The client has adopted innovative procurement initiatives for the project. Tagging along the works that are contracted out on a traditional design-bid-build approach are six Guaranteed Maximum Price (GMP) packages allowing design leverage and buildability scope on the part of the main and subcontractors. In addition, several contractual initiatives have also been pioneered in the project. It is under these innovative initiatives that various stakeholders of the project are engaged. We explore first the procurement arrangement in the next section.

\subsubsection{Procurement arrangement}

All works for the project were contracted via the traditional approach. The contract used for the project is the Government of Hong Kong General Conditions of Contract for Building Works (1993 Edition). Special conditions were added to the contract for the six GMP work packages. These six packages are: (1) the specialist external works (including the footbridge, lift tower, double-deck walkway, covered walkway and miscellaneous external works); (2) the enclosure to drainage reserve and the associated backfilling works; (3) the plumbing and drainage installation (including both the above and below ground drainage works); (4) the fire services and associated water pump installation; (5) electrical installation and (6) the superstructure of the domestic blocks other than the main structural frame. The majority of 
the packages involves design-and-build arrangement. The building services packages (i.e. the plumbing, electrical and fire services), however, involve only installation works with design provided by the client. These packages collectively represent some $30 \%$ of the project cost.

The procurement method is essentially a risk-reduced model developed from the private sector approach to target cost and GMP contracting. Risk reduction for the client is mainly realised through the contractor having to assume the risk associated with the design, development and the construction of the works, and the contractor's commitment on a price ceiling based on his design proposal at the start of the project. Two risk factors are particularly relevant for the project. These are the construction and excavation works at an extremely close proximity to the underground railway line and an existing live gas offtake station. The management of these risks is not only the responsibility of the main contractor, but is also vitally important because the contractor is also involved in the design of the works for these areas.

In addition to risks mitigation, the procurement approach enables the client to potentially reduce claims, integrate the diverse interests of a complex construction project, offers the contractor an incentive to provide value-added services by assimilating the contractor's expertise in the design and innovations in construction methods and materials to enhance buildability (Chan et al., 2007). For the latter consideration, the contractor is rewarded for his creativity and improvement efforts on the design and construction of the works. The procurement route is depicted in Figure 13.1. The stages are briefly explained in the following paragraph.

In the design stage, the client identified work packages that require the integration of the contractor's input in design and buildability. The client then prepared a basic scheme design and performance specification for the work packages. These packages were subjected to subsequent detailed design development by the contractor. At the tender stage, due to the novel nature of the procurement method and the technical risks involved in the project, tenderers were invited from a pool of preferred contractors. These contractors had demonstrated their established track record in the areas of corporate strength, partnering commitments, capability to deliver a quality product, good safety and environmental performance, and experience with GMP arrangements. In so doing, the client hoped to achieve a balance between ensuring effective competition and selecting competent contractors. Tenderers submitted technical proposals for the modified GMP packages. Assessment was done on both technical and price evaluations. The ratio adopted was $70 / 30$ on price to technical score. Tender interviews were conducted with the tenderers' teams. Criteria assessed for the technical category comprised of methodology and technical proposal for the work packages; the resources and expertise of the tenderer; relevant project experience; and safety, health, environment, and resources management of the tenderer. The exercise aims to exclude exceptionally low bids. Instead, the contractor was selected based on the best value offered considering the benefits of buildability, compliance to the specification, alternative design and construction proposal, future maintainability, and cost effectiveness. Because of the unique nature of the procurement arrangement that involves a design-and-build element, the GMP subcontract packages were let as domestic subcontracts. At the construction stage, the GMP packages operated under the 'open book' accounting arrangement where the client could 'see' the contractor's costs at both the tender and construction stage. It is said that the client can therefore understand the contractor's costs better. The improved understanding helped to facilitate mutual efforts in driving costs but not margins down. Given this context, we turn now to examine how various stakeholders are managed through a series of mechanisms.

Constructive engagement was implemented throughout the supply chain from the primary project stakeholders (the project team, the client, the subcontractors and suppliers) and secondary stakeholders (the community) in the project. These initiatives target each stakeholder's main concerns and attempt to match them. The avenues used in this aspect include shared saving among the main stakeholders of the client, main contractor and subcontractors; 


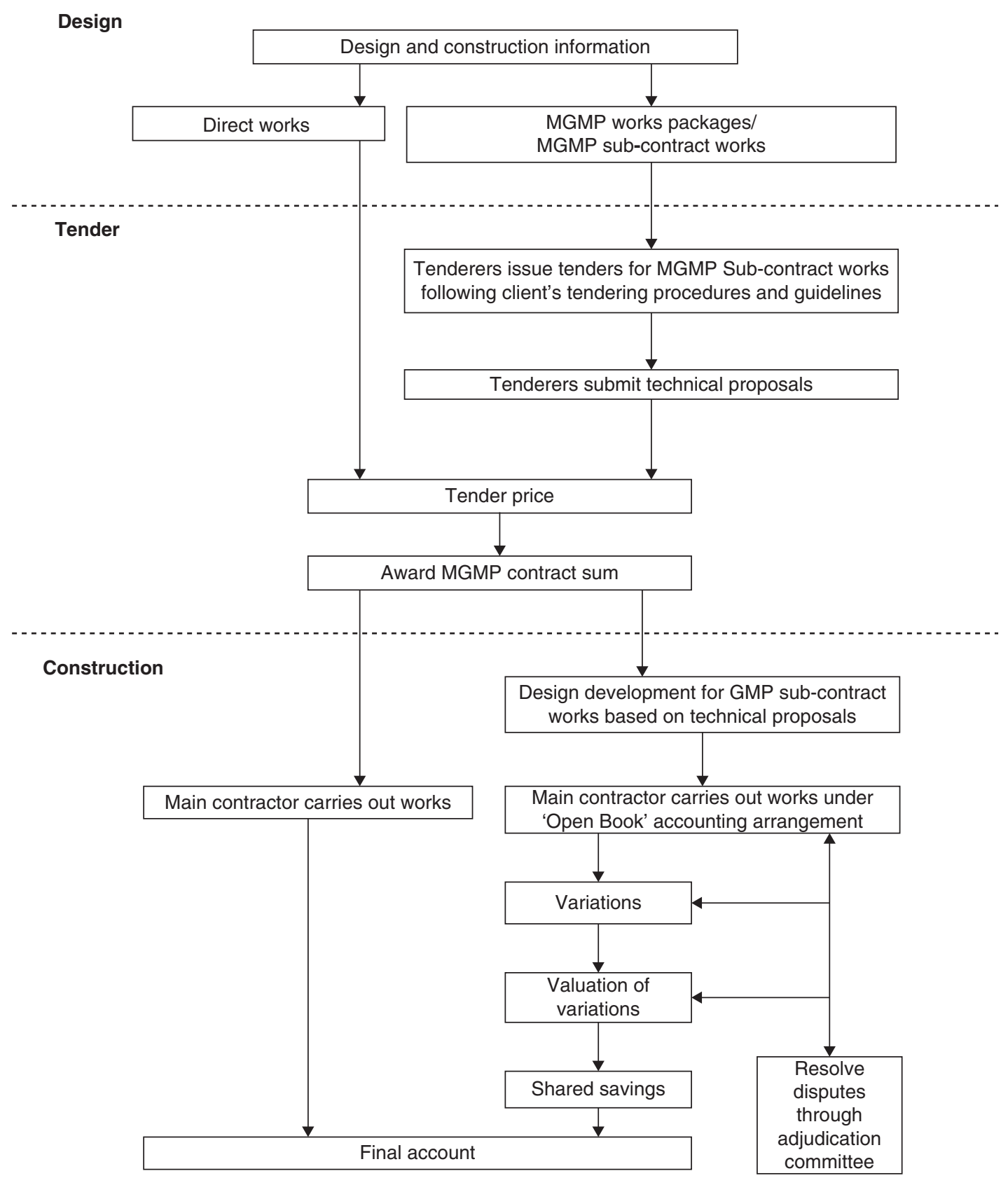

Figure 13.1 The contract procurement route (adapted with permission from HKHA (2005).

ensuring community benefits through various schemes administered by the main and subcontractors endorsed by the client; ensuring workforce benefits and welfare; and project team members' human resource development. From the perspective of stakeholder management, the two salient thrusts in driving these initiatives are client proactiveness and farsightedness, and the main contractor 'coming-of-age' CSR awareness and its manifestations. 
We discuss first the primary stakeholder management initiatives as administered by the client for the project. The impact of the procurement method on stakeholder management is manifested in the institution of supporting mechanisms that are crucial for the successful implementation of the procurement method. These mechanisms are: (1) 'gain share and pain share' arrangement, (2) project dispute resolution system and (3) promotion of a collaborative work environment.

Unlike the traditional GMP scheme whereby the sharing arrangement is only limited to the gain (Chan et al., 2007), both the 'pain and gain' are shared for the project. The cost saving for GMP packages is shared equally between the client and the main contractor, i.e. $50 \%: 50 \%$. However, the contractor is only entitled to $15 \%$ of his portion of the saving. The remaining $85 \%$ is to be shared between the contractor and the GMP subcontractor(s) on a pro rata basis based on the contribution to net savings by both parties. This arrangement potentially motivates both the main and subcontractor(s). The project dispute resolution system is implemented to resolve disputes that might arise at source. The system laid down steps for amicable dispute resolution by inaugurating an adjudication committee. The committee comprised representatives from the client, the main contractor, subcontractors and the quantity surveyor. Under the system, the aggrieved parties first attempt to settle their dispute/ $\mathrm{s}$ in good faith through the adjudication committee. If this step fails, the dispute will then be referred to the senior management of both parties. Arbitration is used as the last resort. An independent dispute resolution advisor is appointed to facilitate the resolution process. Clearly, a collaborative environment is fundamental in smoothening project works. As with most of the government projects, team spirit of the project is developed through a partnering approach. While minor disagreements were present, generally it was observed that better communication and understanding were achieved among the main contractor and client teams. Informal 'workshops' convened by the project architect especially at the beginning stage of the project were particularly effective in promoting cooperation among various parties. Although originally intended to solve technical problems, the constant contacts of participants throughout the workshop sessions had produced a 'side effect' of improving relationships due to close and frequent contacts. More problems were solved promptly on site. The parties became more proactive in working towards achieving common objectives. The cordial relationship between the client and main contractor's team was evident through an incident where both parties waived the design processing costs for the GMP packages. It appears that the procurement method with its associated supporting mechanisms facilitated positive stakeholder management.

There are other general initiatives adopted by the client which are not specific to the GMP procurement method. The main contractor's active participation also contributed to the smooth implementation of these initiatives.

The first initiative is the workers wage protection scheme. The scheme is a direct response to workers' grave concerns on the protection of their wages in the event of default by contractor or subcontractor as evident in recent cases (Lau, 2008). The institution of an on-demand bond in the contract can be used to secure payment of wages for the affected workers. Active monitoring of workers' wages is effected at operational level. A labour relations officer (LRO) is employed on site to check, verify and monitor workers' wage records. The LRO also receives, acknowledges and records complaints, and follows up those complaints on site. Active engagement and participation are required at the lower stream of the supply chain. Both the main and subcontractors are required to operate under the wages declaration system. Under the system, the subcontractors are required to pay their workers on time before applying to the main contractor for their monthly payment in conjunction with works done. On time payment to workers was stressed for the project. The computerised wage monitoring system employed on the project is equipped with a sophisticated mechanism to track 
wage payment such that if late payment to the workers is encountered, the system issues a warning and the subcontractor's payment will be delayed. As cash flow is vitally important to the subcontractors, it appears that information technology has been disguised as a powerful administrative instrument instituted to monitor workers' wages. The main contractor's responsibility is to implement and maintain the computerised system, and to manage the subcontractors' payments. The workers, then, are responsible to actively report work through the system with the use of their access passes.

The main contractor of the project has also adopted other primary stakeholder management initiatives. These initiatives concern mainly the onsite welfare provision for the workers and staff, and human resource development for the main contractor's site management team. The former involves a health promotion programme that includes basic health check and health counselling for workers with health conditions (e.g. hypertension), cash prizes for high performing workers, heat stress preventive programme in view of the high temperature summer working periods, the provision of mobile mist generating machines, installation of thermometers throughout the site, the provision of workers' quarters and laundry areas, etc. The latter initiatives address the project team members' concerns for their personal development and enrichment. The team members have been encouraged and sent to attend various personal development courses that include management skills, technical skills and leadership courses. However, what is more pertinent to the human resource development drive by the main contractor is the great length the main contractor went to in order to emphasise the shaping of a familial atmosphere among the site team. Chief of those initiatives administered by the main contractor, through the senior management staff on site (e.g. project manager and site agent), are the coaching programme, recognition, and the active seeking and provision of opportunities for site staff to try new things within their capability. A systematic recognition and promotion scheme (both financial and positional rewards) was administered in the project. The results observed were the promotions of some site staff and the re-joining of some junior engineers after the completion of their industrial training with the main contractor. In addition, various industrial awards and accolades won by the main contractor in recent times have attested to the efficacy of the approach adopted. The observation is in line with studies conducted elsewhere that indicate the clan type culture that emphasises people orientation is more conducive to successful project outcomes, albeit in the area of quality management (Thomas et al., 2002).

The management of secondary stakeholders, in particular, on the part of the client has seen a saliency in the client's proactiveness in engaging stakeholders. The client identified principal stakeholders as those who are an integral part of their development and construction operations. Of importance is the recognition of the essential roles the stakeholders play in meeting their visions. The client has built into their planning and development processes community engagement initiatives. For the project, a series of activities designed to instill a greater sense of belonging and participation of the community in the project were implemented. A competition for mural painting was organised in the community in conjunction with the project. The winning design had been incorporated as a permanent mural feature for the estate. 'Action Seedling' was another activity implemented to promote community participation in the project. The community was encouraged to participate in the greening of the project during the construction stage. In this activity, local residents and school children from nearby schools participated in planting seedlings and nursing the plants for the estate under construction. In addition, the adoption of construction technology also contributed to the betterment of the community. Extensive use of prefabricated building elements and hard paved site areas are two technological measures aimed at reducing dust and noise.

It is apparent that all the activities cannot be smoothly rolled out without the active participation of the main contractor. In what appears to be the response to the client's push for 
active community engagement at the beginning, the notion of CSR has gradually evolved throughout the organisation of the main contractor over time. As a result of the increased awareness of the impact of their activities on the community, the contractor has been active in participating and responding to the client's drive for community engagement, at times, going beyond the requirements of the client. Two incidents exemplify the contractor's active involvement. The first involved the contractor's volunteer house improvement activities during a festival to help the elderly residents at the nearby estate. The main contractor dispatched two teams of personnel to help repair malfunctioning services within the flats of elderly residents. The second concerned the main contractor volunteering construction related information to the nearby residents in terms of prolonging construction activities beyond normal working hours (i.e., $7.00 \mathrm{pm}$ ). The improved communication between the project team (both the client and main contractor teams) and the community resulted in reduced complaints and a more positive impression from the residents.

The stakeholder management initiatives in terms of the identified stakeholders, their interests, impacts and the strategies adopted to address their concerns are summarised in Table 13.1 at the end of the next section.

\subsubsection{Implications from case study A}

Several implications can be drawn from the foregoing discussions of the project stakeholder management in this project.

\section{Passive reaction among the subcontractors and junior staff members}

The passive reaction refers mainly to the initiation and participation of the parties in the implementation of stakeholder management. The situation is particularly evident in the management of secondary stakeholders. For the project, initiation of stakeholder management was mainly driven by the management of the client and the main contractor. Little effort came from the lower echelon of the project organisation. The contribution from this hierarchy of members came mainly in the form of carrying out instructions from their supervisors/ managers. It appears, therefore, that the members of the lower echelon are adopting a minimalist approach. For these members, engaging with the external stakeholders does not readily contribute to their immediate works. As both the main contractor and the client are fully committed to the stakeholder management paradigm, the issue is one of engaging the lower echelon of the project organisation so that a uniform and positive attitude can be inculcated.

\section{The lack of a structured approach to project stakeholder management}

The preceding observation is symptomatic of the present issue of the lack of a structured project stakeholder management system on the part of the main contractor. The deficiency is particularly acute with external stakeholder management. Despite considerable success in dealing with and tackling issues with the community, the main contractor admitted that their approach was one of trial-and-error and experimentation. Most of the stakeholder management initiatives rolled out in the project were implemented for the first time, at times without thorough deliberation. For the main contractor, while there are elaborate procedures and guidelines dealing with the internal stakeholders, the guidelines for managing external stakeholders, especially the communal stakeholders (e.g. surrounding residents, property and estate management agency, and district councillors), had not been established. Some of the initiatives appear ad hoc. In particular, there was no structured approach to identify external stakeholders, their impacts and the method of engaging them; yet methodologies currently 
Table 13.1 Stakeholder management initiatives for the case project

\begin{tabular}{|c|c|c|c|}
\hline Stakeholder & Stakeholder interest & Impact & Strategy \\
\hline \multicolumn{4}{|c|}{ Procurement-specific initiatives } \\
\hline Client & $\begin{array}{l}\text { Embraced contractor } \\
\text { expertise, improved } \\
\text { buildability }\end{array}$ & Less buildable design & $\begin{array}{l}\text { Design-and-build } \\
\text { element in the GMP } \\
\text { packages }\end{array}$ \\
\hline Client & $\begin{array}{l}\text { Cost certainty, risk } \\
\text { reduction }\end{array}$ & Cost escalation & Introduce GMP scheme \\
\hline Main contractor & $\begin{array}{l}\text { Equitable cost and risk } \\
\text { sharing }\end{array}$ & Cost escalation & $\begin{array}{l}\text { Client administers pain } \\
\text { and gain share scheme }\end{array}$ \\
\hline Subcontractors & $\begin{array}{l}\text { Enjoy the benefit of } \\
\text { saving }\end{array}$ & $\begin{array}{l}\text { Less motivated to } \\
\text { suggest buildable design }\end{array}$ & $\begin{array}{l}\text { Client administer pain } \\
\text { and gain share scheme }\end{array}$ \\
\hline $\begin{array}{l}\text { Client, main contractor } \\
\text { and subcontractors }\end{array}$ & $\begin{array}{l}\text { Better disputes } \\
\text { resolution }\end{array}$ & $\begin{array}{l}\text { Cost escalation, delay } \\
\text { and negative relations } \\
\text { among parties }\end{array}$ & $\begin{array}{l}\text { Client administers } \\
\text { dispute resolution } \\
\text { advisor system }\end{array}$ \\
\hline $\begin{array}{l}\text { Client, main contractor } \\
\text { and subcontractors }\end{array}$ & $\begin{array}{l}\text { More amicable working } \\
\text { environment }\end{array}$ & $\begin{array}{l}\text { Negative and adversarial } \\
\text { working relationships }\end{array}$ & $\begin{array}{l}\text { Developing team } \\
\text { spirit through project } \\
\text { partnering }\end{array}$ \\
\hline \multicolumn{4}{|l|}{ General initiatives } \\
\hline Workers & $\begin{array}{l}\text { Prompt payment of } \\
\text { wages }\end{array}$ & $\begin{array}{l}\text { Low morale, work } \\
\text { stoppage }\end{array}$ & Wage protection scheme \\
\hline Workers & $\begin{array}{l}\text { Welfare and safe working } \\
\text { environment }\end{array}$ & $\begin{array}{l}\text { Low morale, lost } \\
\text { productivity due to } \\
\text { incident/accident }\end{array}$ & $\begin{array}{l}\text { Main contractor provides } \\
\text { safe and comfortable } \\
\text { working environment, } \\
\text { health promotion }\end{array}$ \\
\hline Project team members & $\begin{array}{l}\text { Self-improvement and } \\
\text { promotion }\end{array}$ & $\begin{array}{l}\text { Low morale and } \\
\text { productivity }\end{array}$ & $\begin{array}{l}\text { Main contractor } \\
\text { implements human } \\
\text { resources development }\end{array}$ \\
\hline Project team members & Familial working team & Low morale & $\begin{array}{l}\text { Main contractor's project } \\
\text { manager promotes team } \\
\text { cohesion }\end{array}$ \\
\hline Client, main contractor & $\begin{array}{l}\text { Organisation and } \\
\text { company image }\end{array}$ & Negative publicity & $\begin{array}{l}\text { Active engagement with } \\
\text { community and public to } \\
\text { improve communication } \\
\text { and impression }\end{array}$ \\
\hline Client, main contractor & $\begin{array}{l}\text { To be recognised as } \\
\text { socially responsible } \\
\text { corporate entity }\end{array}$ & Bad corporate image & $\begin{array}{l}\text { Active implementation } \\
\text { of corporate social } \\
\text { responsible activities }\end{array}$ \\
\hline Community and public & $\begin{array}{l}\text { Participation in the } \\
\text { development of estate }\end{array}$ & More complaints & $\begin{array}{l}\text { Client and main } \\
\text { contractor's engagement } \\
\text { activities and } \\
\text { communication sessions }\end{array}$ \\
\hline Community and public & $\begin{array}{l}\text { Less disruption of their } \\
\text { living environment }\end{array}$ & More complaints & $\begin{array}{l}\text { Noise and dust reduction } \\
\text { construction methods }\end{array}$ \\
\hline $\begin{array}{l}\text { Elderly residents at } \\
\text { adjacent estate }\end{array}$ & $\begin{array}{l}\text { Malfunction within-unit } \\
\text { services repaired at low } \\
\text { or no cost }\end{array}$ & $(\mathrm{NA})$ & $\begin{array}{l}\text { Main contractor free } \\
\text { attendance to the units }\end{array}$ \\
\hline
\end{tabular}


exist for their identification and management (see, for example, Walker et al., 2008). The main contractor appears to be passive in that they were taking the cue from the client. However, the client, apart from stating an intention and commitment at the strategic level, did not provide an actionable guideline to the main contractor. While the efforts and achievement of the main contractor have to be commended, the situation reflects the somehow parochial mentality of the construction fraternity in terms of external stakeholder management.

Contracting firms have traditionally adopted the attitude that construction operations are confined within the boundary of the site. Site operations are therefore a closed system. This view overlooks both the direct (e.g. dust and noise) and indirect impact (e.g. bad impression resultant from direct impact) on the community. In terms of engaging external stakeholders and mitigating the impacts construction activities have caused, it is not in the interest of firms to do more than necessary as costs are incurred in extra efforts. Hence shareholder management and interest still overrides the stakeholder paradigm. The project is typically not described and hence not operated in terms of external stakeholders' interests. That is, the stakeholders' perspectives are not integrated into the project formulation processes despite the best intentions of both parties (cf. Cleland and Ireland, 2007).

\section{No allowance for additional resources for stakeholder management}

Despite the various external stakeholder management activities that had been carried out by the main contractor, there was no provision of additional resources available for the main contractor under the contract. The reward from the client comes in the form of recognition. Both the client and the main contractor are fully committed to making the project a success in most if not all aspects. In addition, given its status as a pilot project, the ensuing image issues and the high stakes involved especially for the two primary stakeholders of the client and main contractor (Mahesh et al., 2007), the main contractor resorted to adsorbing the extra costs. However, while the costs involved in carrying out those activities are not considerably large, the lack of compensation from the client may lead to only token efforts from the main contractor. The situation may be more acute for the cost conscious contractor. It is therefore desirable to provide some financial support and introduce an appropriate disbursement mechanism to entice the main contractors to exert effort in managing external stakeholders.

\section{Engagement of specialist subcontractors from the client's nominated list}

The subcontractors for two GMP packages were 'novated' from the client's nominated list, but because of the nature and element of design-and-build inherent in the packages, these subcontractors were engaged as domestic subcontractors. The arrangement is seen as a move to improve the buildability thereby achieving a cost saving design. However, although the arrangement helps ensure quality control to some extent for the client, it can reduce the main contractor's capacity to stay within the GMP (Haley and Shaw, 2002). In addition, the level of cooperation between these novated subcontractors and the main contractor needs extra attention and promotion. For this project, it was observed that the client's intervention was invoked in the initial stage of the project to bring the parties together. In the long run, however, a more appropriate arrangement needs to be implemented.

\subsection{Project description - Case study B}

The project is an infrastructure project, comprising a $1.1 \mathrm{~km}$ elevated viaduct dual three-lane carriageway (average $65 \mathrm{~m}$ above ground) connecting a tunnel (under construction) on one end, to a cable-stayed bridge (under construction) at the other end. Together, they form an 
integral part of a $7.6 \mathrm{~km}$ long major highway. The project site is reclaimed land (to be handed over in phases) surrounded by industrial facilities, container terminals and an educational institution. The contract is a re-measurement type, traditional design-bid-build approach, with an initial contract period of 40 months. There is also a non-contractual partnering arrangement in place. The client is a major works department of the Government of Hong Kong and the contractor is a joint venture between a Hong Kong-based French company and a Chinese state-owned company. The consulting engineer is a Hong Kong-based international engineering consulting firm.

The peculiar features of this project, especially its size, location (vertically and laterally) and technical complexity, brought together a myriad of stakeholders, whose interests needed to be aligned at various phases to successfully deliver the project.

In the next section(s), the management of stakeholders on the project is analysed using data gathered through documentary records and interviews with key project participants. Five incidents, involving critical and contentious issues during the construction phase of the project, are used to illustrate how the stakeholders surrounding each incident were identified, managed or mismanaged individually and collectively in resolving the various issues, as in case A. The impact of the procurement arrangement on the configuration of the project stakeholders and the implications for their management are also discussed.

\subsubsection{Incident analysis}

\section{Interface arrangement}

The contractor proposed sometime after the commencement of the project to change the nature of the original arrangement regarding the temporal use of the deck of an adjoining bridge project (under construction), as a platform to station a launching girder in order to manoeuvre and launch viaduct segments. The proposed change was to position the launching girder beyond the point originally proposed in their technical proposal at tender and which was subsequently built into the contract as an interface arrangement. From the contractor's perspective, however, the change was necessary to make the launching operation simpler and safer. Yet, given the significant shift from the original plan, the new proposal had various implications for progress and risks. In particular, late resolution of the issue could jeopardise the achievement of the project Key Dates. To resolve this issue, however, the input and buy-in of a host of stakeholders were required. The stakeholders in this incident comprised the following, both internal and external to the viaduct project organisation:

1. The Client (same for both projects)

[AQ1\} 2. Viaduct Contractor (viaduct JV contractor)

3. Independent Checking Engineer (ICE)

[AQ1\} 4. Bridge Contractor (bridge JV contractor)

5. Engineer's Representative (ER) (viaduct project)

6. Engineer's Representative (bridge project)

[AQ1\} 7. The Engineer (viaduct project)

8. The Engineer (bridge project)

9. Project Board of Directors (Viaduct JV Contractor)

10. Project Board of Directors (Bridge JV Contractor)

A number of critical and contentious issues regarding the new proposal were apparent.

1. The structural stability of the bridge deck to withstand the imposed loads beyond the original point needed to be established. 
2. Cast-in items were required on the pier and bridge deck to facilitate the positioning of the launching girder.

3. Partial removal of some of the temporary supports to the bridge deck was required to avoid collision with parts of the launching girder.

4. The works programme could be derailed if the issue was not resolved in a timely manner, jeopardising the achievement of Key Dates.

5. Responsibility for the risk and liability for any unforeseen circumstances regarding the proposed operations needed to be established.

6. Associated cost and time liability needed to be established.

It was therefore the contractor's responsibility to obtain buy-in of the various stakeholders identified above to resolve all of the above issues of contention. In doing so, the stakeholders were engaged both formally and informally. For example, the issues regarding the structural stability, partial removal of temporary supports and cast-in items, which were within the domain of the Bridge Contractor, were discussed in the first instance at their regular monthly interface meeting. At this meeting, the Bridge Contractor agreed in principle to check the feasibility of the issues raised and to give its response.

While the first three issues, which were technical in nature, were easier to resolve with the Bridge Contractor, the last three, which were contractual, were most problematic. In terms of risk and liability regarding damage to the bride deck works, this was covered under an Owner Controlled Insurance Programme (OCIP) taken by the client to cover all the projects within the $7.6 \mathrm{~km}$ highway. The contentious issue was however with potential claims from either contractor for extension of time or associated cost due to any unforeseen prolongation arising from the proposed arrangement. It became significantly more contentious when the client requested that The Engineers of both projects get undertakings from their respective contractors not to claim time or costs associated with the proposal if approval was granted. Apparently, a similar arrangement on one of the client's previous projects had resulted in huge prolongation claims from one of the contractors and thus reinforced the 'baggage' parties carry from one project to the other. The Client's suggestion was however at variance with the contract provisions in both contracts (the viaduct and the bridge) that allowed the contractor to claim extension of time and additional payment for interface issues if the issue requires the contractor to act in a manner which goes beyond his obligations under the interface provision. The ER on the viaduct project however consequently requested a full risk assessment on the issue from the contractor, emphasising as well that the client would only give consent for the proposal to go ahead if the Viaduct Contractor was willing to accept full liability for any eventuality. A contingency plan was also requested from the contractor, in the event that the proposal was not approved by the client.

To obtain buy-in of all parties regarding the viability of their proposal, the Viaduct Contractor organised and delivered a presentation on the sequences involved in their new proposal regarding the use of the bridge deck. Yet, this did little to persuade the parties to shift their positions. The Client maintained his position of no approval without waiver of rights to claim time and associated cost by the contractors. The contractors also maintained that they could not waive that right. While this was generally a contractual matter, it also highlights the cultural disposition of uncertainty avoidance in a Chinese work context and the tendency to work strictly according to the rules (or contract in this case). Not even the double assurance provided by the use of the ICE to provide an independent assessment of the safety and structural soundness of the proposal could persuade the parties to reach an agreement.

At this time it had been about 5 months since the proposal was put forward and there was still no end in sight, and the launching girder was within weeks from the point where access to the bridge deck was required. The Client continued to emphasise the need for an early 
resolution, yet was not prepared to compromise on its stand. All parties then agreed that this

interface issue be resolved as soon as possible and that a drop dead date for a conclusive decision on the proposals be established. As the issue dragged on the contractor's revised works programme could not also be approved, partly because it was contingent on the new proposal and thus failed to meet the established Key Dates. At this stage, the remaining contentious issue unresolved was still that of waiver of right to claim. The Engineer for the viaduct project then wrote to request the contractor to confirm their acceptance of all direct and consequential costs if the launching girder was in an accident or incident involving the bridge works resulting in prolongation. The contractor however indicated in three related letters to the ER that they could not accept additional liabilities as that constituted additional constraint under the contract. They further indicated that they were studying alternative temporary works to enable the undertaking of the launching of the segments without using the proposed bridge deck beyond what was originally proposed, but that these had cost implications. In a reply, the ER reminded the contractor of their contractual obligation to indemnify the client irrespective of which proposal they chose to go with. To put an end to the ping-pong letters that were becoming the main mode of communication regarding this issue, a meeting was then scheduled to specifically deal with the issue. However, as the issue could not be resolved, the contractor was requested to revert to the original sequence of segment erection in the technical proposal at tender or submit alternative proposals for consideration. Out of options and running out of time as well, the contractor agreed to revert to the original proposal and thus prepared and submitted a proposal to the ER accordingly. This proposal included a method statement, risk assessment, detailed interface arrangement and various ICE certificates as required. This was approved by the ER. As this was also the outstanding issue making it impossible to have the revised programme of works approved, the contractor also prepared and submitted the programme in line with the original arrangement.

Evidently, about 6 months was spent needlessly, only to revert to the original proposal. Ironically, the segment launching operation which was the subject of about 6 months back and forth discussion and 'ping-pong letters' actually took less than 3 weeks to complete after reverting to the original plan. It is interesting also that the various stakeholders in this, especially The Client, took positions that appeared at variance with the spirit of the non-contractual partnering that was in place on the project and that was continuously reinforced through various workshops. Indeed, an attempt to use the partnering process to resolve this issue was met with silence from all parties, reinforcing the sceptics' belief that many parties who sign up to such non-contractual partnering arrangements have little commitment to working in 'real' partnership. One of The Client's team members was particularly unequivocal when he put it rather bluntly in an interview that:

Under the partnering spirit, we organize ... workshops and ... discussions with facilitator where we can express our opinion, ... but still the roles of the engineer, the employer and the contractor are still clear under the contract. ... partnering ... [is] there to facilitate any exchange of opinions, but not as a forum for making decisions. . . It is not a forum for making decisions. Of course, we have our own decision, whether to proceed with a certain idea, but that's not contractual. So you have to slightly distinguish this...

While there appear to have been genuine efforts by the contractor (may be because the contractor stood to benefit most if the proposal was approved) to engage and obtain buy-in, it is doubtful whether any alternative mode of engaging, especially The Client, could have yielded a different outcome. Public project settings are particularly replete with risk averse and fear of blame attitudes. This, rather than the means of engagement of the parties, may be why a proposal such as this was predisposed to failure. 
In a related incident a couple of months later, the Bridge Contractor needed to erect cranes on the same bridge deck area. Given the elevated nature of the bridge (about $70 \mathrm{~m}$ above ground), the only viable access point to the deck was through the viaduct, as the other end of the bridge under construction was still hanging over water (sea). The Bridge Contractor therefore requested to use the viaduct in order to move the cranes and associated equipment to the bridge deck. This proposal was accepted, apparently because the trucks and crane parts that were to be delivered were not expected to impose any loads beyond what the viaduct has been designed to withstand. Given that the element of uncertainty was greatly reduced in this case, a resolution was a straightforward matter. But more importantly, this suggests that when two projects share boundaries like this, interdependence is inevitable. Thus, parties must always remember that often, 'what goes around, comes around'. If the Bridge Deck Contractor had refused to consider the proposal put forth by the Viaduct Contractor to extend use of the bridge deck, then the Viaduct Contractor could also have used that precedent to refuse access to the viaduct or unnecessarily delay the granting of such access.

\section{Temporary Traffic Arrangement}

To facilitate the works and safeguard the public, it was necessary from time to time during the project to temporarily divert traffic passing through the site. This normally involved full or partial closure of some or all roads. These changes to the normal movement of traffic are handled under what is called 'Temporary Traffic Arrangement' (TTA), and is governed by the 'Code of Practice for the Lighting, Signing and Guarding of Road Works' 4th issue which came into force on the 1 July 2007. This incident revolves around the TTA schemes on the project and how they were managed to reduce non-compliance (NC) and inconvenience to the public and the engagement of various stakeholders.

The stakeholders in the TTA schemes included the following:

1. Road users (General Public)

2. Client's Audit Team (Research and Development section)

3. Traffic Management Liaison Group (TMLG) (which comprised the Client, Contractor (and his Transport Consultant), ER, Police (Road Management Office and Traffic Management Bureau), Transport Department (Engineering and Operations section), Representatives of Adjoining Businesses, Lands Department, Local Council representative)

The key stakeholder was the TMLG, whose decisions supersede the contract provisions regarding the TTAs. The key players in the TMLG were the police and the Transport Department, with the other members tending to go with whatever these two decided.

The contractor and his Transport Consultant were responsible for the design of the TTAs. The proposed arrangements are then presented to the TMLG for deliberation and approval. Once approved, the TTA becomes the standard against which NC is determined. Given the importance The Client attaches to the TTAs, an Audit Team (the Research and Development section) carries out on average about 10 audits every month regarding the performance of TTAs and issues NC for breaches.

For several consecutive months in the course of the project, the Audit Team continually issued NCs for various breaches. The Client's project team expressed their unhappiness about the situation and asked the ER to step up their own inspections to forestall any future breaches. It was then agreed that representatives of the ER and the contractor would check on a daily basis to ensure that the TTAs were implemented to the required standard.

The ER together with the contractor then instituted various measures to prevent contraventions of the TTA arrangements. Central to this was increased joint inspections. Three 
inspections of the TTAs were carried out daily. The first inspection often took place in the morning where breaches were identified for rectification. In the afternoon the ER carried out another inspection to ascertain that the breaches that were identified in the morning had been rectified. The last inspection was then undertaken jointly by the ER and contractor at about $4 \mathrm{pm}$ to make sure all TTAs are still in order. Following the success of these measures in reducing the NCs to zero for the following months, the Client suggested that the ER circulate such measures to the Client's other projects for possible use, since they were apparently having similar problems. In a show of support for the contractor's efforts in upholding the standards regarding the TTAs, the Client's project team personally appealed on one occasion on behalf of the contractor when the Audit Team issued an NC which the Client's team thought was unfair. The inspection team subsequently withdrew the NC.

The management of public expectations was also central to the success of the TTAs. To help reduce the inconvenience, the TTAs sometimes caused to the public, the Client was usually given 3 days advance notice by e-mail or phone of all future TTA leading to diversions or road closures to allow their prior notification to concerned members of the public.

Feedback from the public was also a central element of the TTA implementation, since it was often not possible to envisage and cater for the expectations of all road users. Although not exclusive to this project, the Government of Hong Kong has in place various channels through which the public can send in enquiries and complaints on a wide range of issues including issues relating to roadwork activities such as TTAs. The most commonly used channel is 1823 Citizens Easy Link (CEL). This is an integrated contact centre operated by the Efficiency Unit of the Government of Hong Kong on behalf of about 20 Government

[AQ1\} Departments including all works departments. Once a complaint is received, it is processed and passed on to the department of concern. In addition to this, the client also runs a 24-hour hotline, enquiry and complaint e-mail addresses. When the client receives a complaint regarding, for example, the TTAs on the project, the complainant is usually contacted for further details or clarifications. These are then passed on to the ER or contractor for appropriate actions. A range of actions are possible depending on the content of the complaint, but could include inviting the complainant on a joint site visit to better understand the problem for a more appropriate resolution. Indeed, the Client has made a pledge to resolve all complaints within 7 days. If this is not possible, complainants are normally sent a preliminary response on progress of resolving their concern with information on when they expect to completely resolve the situation. On this project in particular, they have instituted what they call the complaint walk where the client goes on site to walk through with the ER and contractor to ensure that the complaints from the public are being addressed. In one episode, a lorry driver launched a complaint when he was affected by the closure of one of the roads passing through the project site. The issue was resolved to his satisfaction by the installation of additional traffic signs. The Client then advised that the planning and implementation of the TTAs should take into account the perceptions of the road users in addition to meeting the minimum standards. In another episode, a passenger had to pay an additional HK\$30 as taxi fare due to diversions resulting from a TTA. He launched a complaint regarding this and was taken on a site visit to explain the situation. However, he was dissatisfied with the explanation and demanded a refund of his taxi fare. This was rejected by the contractor as it was considered unjustified as all the necessary signage was complied with. The passenger was considering taking the issue up with the ombudsman.

TTAs are an important feature in roadwork projects and are considered one of the most challenging tasks on most road projects (Chan, 2003). Yet, as shown here, the project team, especially the contractor, is keen on ensuring that inconvenience to the public is reduced as much as possible by engaging all stakeholders for successful implementation of all TTAs. 


\section{Community Planting Exercise}

In December 2003, the Works Bureau of the Hong Kong Government issued a circular (No. 34/2003) on 'community involvement in greening works'. This directive was to show the government's commitment to the promotion of greening activities to enhance the quality of the living environment, and to promote community involvement and a sense of ownership among local residents. It required that all capital works contract with the estimated value of the landscape works in excess of HK\$3 million should involve consultations with the respective district councils with regards to the greening works prior to tender and that the community be invited to participate in the planting works near to or after the completion of the project.

Since the value of the landscape works on the project was less than HK\$3 million, the adjoining bridge project whose value for landscape was also less than HK\$3million was invited to join the community planting exercise. Thus, both the contractor and consultant confirmed that the community planting exercise was not part of the original contract but only in their opinion a public relations exercise by the client. Yet, the ER was quite supportive asserting that:

... I think this is, one of the reasons is to let the public know that [the Client] ... is very keen in greening the environment or [the Client's] projects are not just a concrete bridge, concrete 'spaghettii' built in urban or rural areas but [the Client] at the same time, [the Client] thinks about the aesthetics of the bridge work and [the Client] thinks about what has been affected in terms of the planning so [the Client] tries to compensate the area by putting more plants at the same time [the Client] enhances more greening works.

The details of the onsite community planting on the project were however discussed at one of their monthly progress meetings. The client advised that the exercise be arranged earlier to avoid the hot weather and typhoon season if possible. Following this, the ER (viaduct project) was requested to attend a similar community planting activity being organised by an adjoining project for first-hand information on how it is done, so that he would be in a position to advise the contractor on how to organise for this project.

The key participants for the community planting project were pupils from two selected primary schools in the neighbourhood and some district council members. The contractor however had some concerns about the composition of the volunteers for the planting exercise and expressed some reservations:

... there is some hidden risk in this, because for us at the moment, this is still a construction site, so under the law anybody who comes into the site will require a Green Card. If he is a worker, he needs to have a registration card, ... the kids who will be doing the planting, they are actually doing [the contractor's] work. Technically they are doing our permanent works because they are planting the area where [the contractor] is supposed to plant themselves, so they don't have a green cards, they don't have workers' registration cards and they are all underage (Rep. Contractor)

He added regarding insurance that ' . . technically the insurance people will say, if something happens such as claims issue who is responsible?'.

On the question of whether these issues had been raised with the client, the response was that the volunteers should be classified as visitors. Since the circular on the community planting mandates the Client to take responsibility among others for insurance and safety matters, it was the contractor's view that this has been given due consideration.

Taken together, however, the community planting exercise appears to be well received by the volunteers and attracting public enthusiasm. This can be attributed to the fact that it 
presents them with the opportunity to get closer to projects than they normally would, and in the process learn more about what the tax payer's money pays for. Government and community representatives are also keen to show up at such exercises as it gives them the opportunity to closely engage with and interact with their constituents.

\section{Construction Noise Permit}

Following a proposal to change from the use of two launching girders as proposed in the technical proposal at tender to one launching girder and a crawler crane, the contractor further proposed a 24-hour cycle for the erection of the viaduct segments in order to achieve an equivalent productivity level. While there was no issue with this part of the proposal, as that was within their contractual right, the continuous supply of precast segments to the launching girder beyond $11 \mathrm{pm}$ to ensure the 24-hour cycle was achieved was problematic. This was because the proposed storage area for the precast segments was directly beneath a student hall of residence and the carrier that supplied the segments to this area produced noise beyond the acceptable Environmental Protection Department's (EPD) limits. The stakeholders in this case included:

1. Authorities of Educational Institution

2. The residents of school hall of residents (warden)

3. Environmental Protection Department

4. The Client

5. Viaduct Contractor (viaduct project)

To mitigate the situation, the contractor proposed some modifications to the segment carrier to reduce the noise. A noise enclosure was specifically designed and installed to the engine part of the carrier. A trial was then run and the noise levels at various times and from various points were recoded and the results presented to EPD. Given the importance of this permit to the progress of work, the Client played a key role in facilitating the approval process as testified by the contractor:

... [the Client] was involved in some of the discussions, so, everyone was involved trying to satisfy EPD, even [the Client] went with [the contractor] to discuss with EPD, about what can be done, what is acceptable to [EPD] in terms of noise level from the point of view of EPD for them to issue a permit (Rep. Contractor)

In separate discussions with school authorities whose hall of residence was close by, the contractor suggested that the windows of the hall facing the site be closed at all times to reduce the noise. The school agreed to do so but also requested that the contractor replace their old air-conditioner with a much quieter new one.

While the approval process for this issue took an unusually long time to resolve, it is interesting to note that throughout the 24-hour segment erection operations, only one person (the warden) actually lived in the hall of residence, and thus shows the desire to fully adhere to the law no matter the circumstances.

\section{Miscast segments}

An estimated 67 number precast viaduct segments were miscast by the precast subcontractor due to wrong setting-out information provided. This resulted in the incorporation of crossfalls in the wrong direction. The ER subsequently issued a non-conformity notice which required that the segments be scrapped and recast. In view of the significant and unrecoverable delay to the work that this error could cause, there was the urgent need to review the 
procedures relating to the production of the precast segments in the precast yard in Mainland China, by strengthening supervision. There was therefore an immediate review of the setting out and checking procedures for the production of the precast segments.

The stakeholders in this case included:

1. Precast Subcontractor (in Mainland China)

2. Contractor (Viaduct)

3. Independent Engineering Consultant

4. The Client

5. Client's Maintenance Unit

6. Clients Audit Team

7. Government Department (in charge of waste disposal site)

8 The Engineer

9. The ER

When the error was detected, some of the wrongly cast segments were already erected. The consequence of the errors in the already erected segments was that the alignment of the finished road surface was unlikely to meet the requirements in the specifications. This therefore required that the approval of the Client's maintenance unit and the Transport Department be sought for the acceptance of those works. Given the implications of the lost production time had for the progress of the works, the contractor further proposed incorporating as many of the miscast segments as possible into the works since the errors had no implications for the structural capacity of the viaduct. In line with this, a full report on the segment errors was prepared and submitted to the ER so that the feasibility of further incorporating as many of the miscast segments (without rectification) into the works could be evaluated. The miscast errors were also picked up by the client's technical audit team following their prevention of substandard works audit and called for rectification.

The contractor engaged the services of an engineering consultant to undertake an independent review of the miscast segment situation. The independent review was then submitted to the Client for his comments. Queries were raised by the Client and replied to by the contractor. Following a 'no further objection' from the Client's project team, the contractor submitted the final report to the maintenance unit for approval of the incorporation of as many miscast segments as possible into the works.

While some segments were redeemed and incorporated into the works, about 35 miscast segments became redundant and needed to be discarded. However, the mode of disposal became another issue. The Client proposed that the contractor could consider sinking the miscast segments to the seabed to form an artificial reef. The Client however left it to the contractor to decide on his preferred method of disposing of the miscast segments and with a promise to assist as required. The contractor eventually decided to have them demolished. To facilitate their gaining consent to demolish the miscast segments at a waste disposal site from the Government Department in charge, the contractor requested the Client to provide them with a support letter. The Client agreed and provided them a letter supporting their proposal. The Government Department in charge however rejected the contractor's proposal to demolish the miscast segments at the waste disposal site and noted that the contractor can have them demolished in China where they are still stored in the precast yard.

It is clear here that the consequence of the miscast error for all stakeholders was an incentive to work together for a fruitful resolution of the issue. This demonstrates the power of joint interest or joint risk in motivating stakeholders to work for the common good of the project. Yet, the inability to agree on how to dispose of the remaining precast segments also shows how lack of alignment of interests forestalls consensus building. 


\subsubsection{Impact of procurement arrangement}

This project was procured under a traditional design-bid-build approach. As the most common procurement arrangement in Hong Kong, it presupposes that the parties were generally familiar with the procurement route. Yet, it is apparent from the discussion so far that the arms-length mindset associated with this approach contributed to how some of the incidents played out. It is however commendable that the interface arrangements were built into the contract. This approach clearly defined the interdependence between the two projects from the onset as an issue to be managed during the project. However, the interface arrangement appears to have been structured without consideration for the uncertainties that can arise in a project of this size and complexity. This was further exacerbated by the inflexibility of the various parties. Ironically, there was a non-contractual partnering arrangement in place, in which the parties promised to work in partnership. Yet, when it mattered most all the stakeholders held on to their contractual rights.

The structuring of the project organisation also had implications for the number of stakeholders on any issue and thus their management. First, the Client organisation was a plural one. On many issues, three or more different departments of the Client organisation needed to be satisfied, and this became more problematic when they disagreed. The fact that the contractors on the two adjoining projects were joint ventures also had implications for engaging them. In this case, the board of directors of the JVs appear to have played only a passive role, as most of the issues were considered site matters, which were within the domain of the site teams. Some contractual provisions also had implications for the number of stakeholders who needed to be engaged, e.g. the ER as a separate entity from the Engineer; the use of an ICE, whose role was to independently check all the contractors' designs and the TMLG.

\subsubsection{Implications}

Five incidents have been analysed above to show how stakeholder management on a Hong Kong infrastructure projects manifested itself. The different incidents showed management of relationships among stakeholders internal to the project organisation as well as relationships among stakeholders external to the project. In both cases it was clear that when the stake of all stakeholders on an issue of contention was high, there was a tendency to reach an agreement easily (Table 13.2). Culture-specific dynamics also manifested themselves in the positions different stakeholders took on issues and there was a general tendency to follow or adhere strictly to the contract. This may be attributable to the fear of blame culture pervasive in public project settings and the conflict avoiding view inherent in the Confucian value system.

Taken together, however, this case study demonstrates an element of progress towards public engagement on projects in Hong Kong, an element which was unheard of a decade ago. Yet, the arms-length mindset, perpetuated by decades of use of the traditional procurement arrangement, is still prevalent. Indeed, when collaborative initiatives such as partnering are bolted onto the traditional procurement system, little evidence of real partnership is manifested. Thus, a shift in culture, both in terms of the way stakeholders are engaged and projects are procured, appears a viable option for project delivery in Hong Kong.

\subsection{Conclusion: Lessons learned from the case studies}

It is apparent from the case studies above that tradition, custom and practice, politics and culture have a major influence on how stakeholder management is undertaken in the Hong Kong construction industry. Without a strong tradition of democracy, it is not surprising that 
Table 13.2 Impact of stakes on project developments

\begin{tabular}{|c|c|c|c|}
\hline Stakeholder & Stakeholder interest & Impact & Strategy \\
\hline \multicolumn{4}{|c|}{ Interface arrangement } \\
\hline Viaduct Contractor & $\begin{array}{l}\text { Safer work environment; } \\
\text { simpler site operations }\end{array}$ & $\begin{array}{l}\text { Escalation of risks, } \\
\text { non-achievement of Key } \\
\text { Dates }\end{array}$ & $\begin{array}{l}\text { Buy-in of key } \\
\text { stakeholders; formal and } \\
\text { informal engagement; } \\
\text { interface meetings; ping- } \\
\text { pong letters }\end{array}$ \\
\hline Bridge Contractor & $\begin{array}{l}\text { Structural stability of } \\
\text { bridge }\end{array}$ & Risk and liability & \\
\hline Client & $\begin{array}{l}\text { Limit liability and claims; } \\
\text { structural stability of } \\
\text { bridge }\end{array}$ & $\begin{array}{l}\text { Blame/reprimand from } \\
\text { superiors; escalation of } \\
\text { risk }\end{array}$ & \\
\hline ER & $\begin{array}{l}\text { Projecting Client's } \\
\text { interests; enforcement of } \\
\text { contract }\end{array}$ & Loss of Client's trust & \\
\hline The Engineers & $\begin{array}{l}\text { Projecting Client's } \\
\text { interests; enforcement of } \\
\text { contract }\end{array}$ & Loss of Client's trust & \\
\hline ICE & Neutral assessment & Neutral & \\
\hline $\begin{array}{l}\text { Project Board of } \\
\text { Directors }\end{array}$ & $\begin{array}{l}\text { Safer and simpler site } \\
\text { operations }\end{array}$ & Passive observer & \\
\hline \multicolumn{4}{|c|}{ Temporary Traffic Arrangement } \\
\hline Viaduct Contractor & $\begin{array}{l}\mathrm{NC} \text {, least inconvenience } \\
\text { to road users }\end{array}$ & $\begin{array}{l}\text { Inconvenience to } \\
\text { road users; loss of } \\
\text { reputation of key project } \\
\text { participants; public } \\
\text { complaints }\end{array}$ & $\begin{array}{l}\text { Management of public } \\
\text { expectations; three-cycle } \\
\text { daily joint inspections; } \\
\text { feedback from road } \\
\text { users; complaint walk; } \\
\text { Government's central } \\
\text { complaints unit (1823 } \\
\text { Citizens Easy Link } \\
\text { (CEL)) }\end{array}$ \\
\hline $\begin{array}{l}\text { Road users (general } \\
\text { public) }\end{array}$ & Least inconvenience & & \\
\hline Client & $\begin{array}{l}\text { Reduction in NC, least } \\
\text { inconvenience to road } \\
\text { users }\end{array}$ & & \\
\hline Client's Audit Team & Enforcement of TTA & & \\
\hline ER & $\begin{array}{l}\text { Reduction in NC, least } \\
\text { inconvenience to road } \\
\text { users }\end{array}$ & & \\
\hline TMLG & $\begin{array}{l}\text { Faster resolution of TTA } \\
\text { issues, }\end{array}$ & & \\
\hline
\end{tabular}


Table 13.2 Impact of stakes on project developments (Continued)

\begin{tabular}{|c|c|c|c|}
\hline Stakeholder & Stakeholder interest & Impact & Strategy \\
\hline \multicolumn{4}{|c|}{ Community Planting Exercise } \\
\hline Client & $\begin{array}{l}\text { Community involvement; } \\
\text { PR, promotion sense } \\
\text { of ownership, public } \\
\text { enthusiasm }\end{array}$ & $\begin{array}{l}\text { Public agitation; negative } \\
\text { publicity }\end{array}$ & $\begin{array}{l}\text { Invitation to participate; } \\
\text { community out-reach; } \\
\text { onsite community } \\
\text { planting }\end{array}$ \\
\hline Contractors & $\begin{array}{l}\text { Liability and safety } \\
\text { issues; insurance; } \\
\text { composition of } \\
\text { volunteers }\end{array}$ & Lack of commitment & \\
\hline ER & $\begin{array}{l}\text { Projecting Client's } \\
\text { interests; enforcement of } \\
\text { contract }\end{array}$ & Loss of client's trust & \\
\hline Public (school children) & Participation & & \\
\hline \multicolumn{4}{|c|}{ Construction Noise Permit (CNP) } \\
\hline Contractor & $\begin{array}{l}\text { 24-hour cycle; constant } \\
\text { supply of segments; } \\
\text { storage area }\end{array}$ & Delays to works & $\begin{array}{l}\text { Mitigation measures; } \\
\text { meetings; Government's } \\
\text { central complaints unit } \\
(1823 \text { Citizens Easy Link } \\
(\mathrm{CEL}))\end{array}$ \\
\hline Client & $\begin{array}{l}\text { Noise level; public } \\
\text { complaints }\end{array}$ & $\begin{array}{l}\text { Delays to works; public } \\
\text { complaints }\end{array}$ & \\
\hline $\begin{array}{l}\text { School (hall of } \\
\text { residence) }\end{array}$ & Noise level & $\begin{array}{l}\text { Inconvenience; public } \\
\text { complaints }\end{array}$ & \\
\hline EPD & $\begin{array}{l}\text { Enforcement of noise } \\
\text { regulation }\end{array}$ & & \\
\hline \multicolumn{4}{|l|}{ Miscast segments } \\
\hline $\begin{array}{l}\text { Contractor (precast } \\
\text { subcontractor) }\end{array}$ & $\begin{array}{l}\text { Significant and } \\
\text { unrecoverable delay and } \\
\text { loss of resources }\end{array}$ & $\begin{array}{l}\text { Delays to works; waste } \\
\text { of resources }\end{array}$ & $\begin{array}{l}\text { Review of precast } \\
\text { procedures; } \\
\text { strengthening } \\
\text { supervision; mitigation } \\
\text { measures }\end{array}$ \\
\hline Client Departments/Units & $\begin{array}{l}\text { Build as designed, easy } \\
\text { maintenance }\end{array}$ & Maintenance difficulties & \\
\hline $\begin{array}{l}\text { Engineer's } \\
\text { Representation }\end{array}$ & Enforcement of contract & Damaged reputation & Ping-pong letters \\
\hline ICE & Neutral assessment & Neutral & \\
\hline
\end{tabular}

the move to draw the public, green groups and other parties into the development process has moved forward slowly; there is no evidence of resistance to change, rather an inertia grounded in the traditional values of society and the structure of Government Departments and institutions which puts a brake on change. This is not totally surprising: if one studies the position of Hong Kong on Hofstede's dimensions of culture, it is obvious that nations such as United Kingdom and United States have a value infrastructure which is more open to 


\begin{tabular}{|c|c|c|c|c|}
\hline $\begin{array}{c}\text { Power distance } \\
\text { (high) }\end{array}$ & $\begin{array}{c}\text { Uncertainty } \\
\text { avoidance } \\
\text { (high) }\end{array}$ & $\begin{array}{c}\text { Individualism } \\
\text { (individualistic) }\end{array}$ & $\begin{array}{c}\text { Masculinity } \\
\text { (masculine) }\end{array}$ & $\begin{array}{c}\text { Confucian } \\
\text { dynamism } \\
\text { (long-term } \\
\text { orientation) }\end{array}$ \\
\hline
\end{tabular}

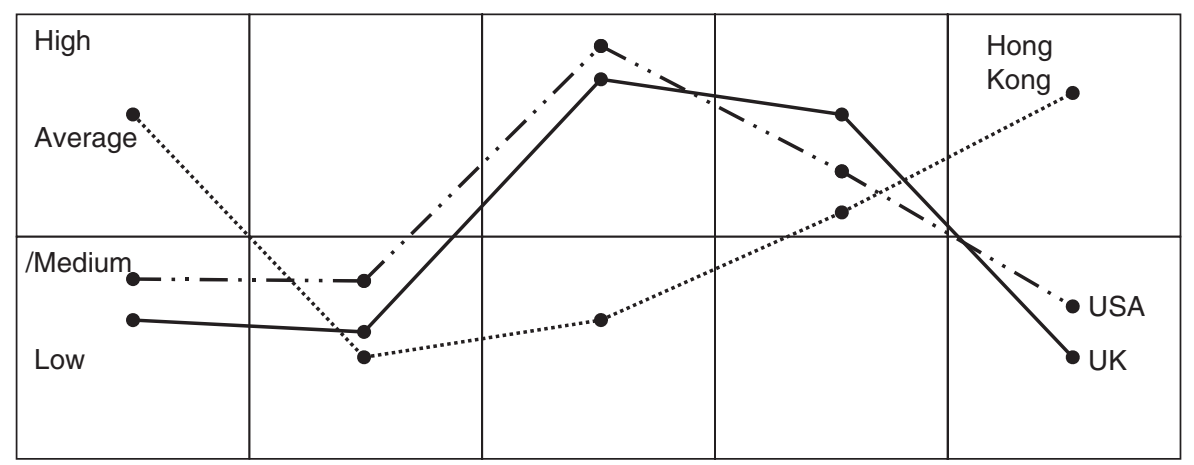

\begin{tabular}{|c|c|c|c|c|}
\hline $\begin{array}{c}\text { Power distance } \\
\text { (low) }\end{array}$ & $\begin{array}{c}\text { Uncertainty } \\
\text { avoidance } \\
\text { (low) }\end{array}$ & $\begin{array}{c}\text { Individualism } \\
\text { (collectivistic) }\end{array}$ & $\begin{array}{c}\text { Masculinity } \\
\text { (feminine) }\end{array}$ & $\begin{array}{c}\text { Confucian } \\
\text { dynamism } \\
\text { (short-term } \\
\text { orientation) }\end{array}$ \\
\hline
\end{tabular}

Figure 13.2 Comparison of Scores for Hong Kong, USA and UK on Hofstede's Cultural Dimensions.

stakeholder involvement and empowerment (Figure 13.2). The Confucian values of harmony and conflict avoidance are often an opposing force to the drive for stakeholder empowerment.

This having been said, there is evidence from the case studies that change is taking place and that the post-colonial administration is becoming more attuned to the legitimate demands of its stakeholders and a 're-education' process is taking place (Table 13.3). This cannot be described as a cultural revolution but a culture change is taking place. A move away from traditional procurement forms is now underway with the Hong Kong Housing Authority leading the way and the Works Bureau departments commencing a range of 'experiments' with more open procurement forms. Indeed, the incorporation of partnering type agreements into many projects has contributed to a change in culture and led to more open attitude to cooperation and collaboration in construction projects (see, for example, Anvuur, 2008). In line with this, there needs to be a recognition that performance measures need to be refocused to take into account medium- and long-term objectives in line with the arguments put forward by Walker et al. (2008).

In recent years, employees and stakeholders have become much more aware of the need for firms and government to show a commitment to CSR (see Rowlinson, 2009) and this has raised awareness in all sectors. Indeed, major infrastructure and property developers have taken on board stakeholder management as part of their CSR commitment; however, time will tell whether this is a marketing fad or a genuine culture change in the industry. With the establishment of the Construction Industry Council in 2008, there is now an industry-wide body dedicated to improving performance in the real estate and construction industries. One of its first tasks has been to improve construction site safety and this has involved an attempt to engage workers, managers and directors in a framework that provides a basis for joint problem-solving and initiative development. Such approaches augur well for the future development of stakeholder management and empowerment in Hong Kong. 
Table 13.3 Stakeholder management issues and strategies

\begin{tabular}{|c|c|c|c|}
\hline Issue & Project & Strategy & Example \\
\hline \multirow[t]{2}{*}{$\begin{array}{l}\text { Procurement } \\
\text { systems } \\
\text { reformation }\end{array}$} & Case A & $\begin{array}{l}\text { Greater contractor participation, } \\
\text { equitable sharing of costs and } \\
\text { benefits }\end{array}$ & $\begin{array}{l}\text { MGMP packages, dispute } \\
\text { resolution system, pain and gain } \\
\text { share scheme }\end{array}$ \\
\hline & Cases $A$ and $B$ & Partnering & $\begin{array}{l}\text { Non-contractual partnering; } \\
\text { interface management }\end{array}$ \\
\hline $\begin{array}{l}\text { Improved } \\
\text { collaboration }\end{array}$ & Cases $A$ and $B$ & Relationship management & $\begin{array}{l}\text { Partnering, promote dialogue } \\
\text { sessions }\end{array}$ \\
\hline \multirow[t]{2}{*}{$\begin{array}{l}\text { Life cycle value } \\
\text { consideration }\end{array}$} & Case A & Life cycle costing & $\begin{array}{l}\text { Design with maintainability in } \\
\text { mind }\end{array}$ \\
\hline & Case B & $\begin{array}{l}\text { Emphasis on what is best for the } \\
\text { project in the long run }\end{array}$ & $\begin{array}{l}\text { Build with maintainability in } \\
\text { mind (incorporation of miscast } \\
\text { segments); Owner Controlled } \\
\text { Insurance Programme (OCIP) }\end{array}$ \\
\hline \multirow[t]{2}{*}{$\begin{array}{l}\text { Community } \\
\text { involvement }\end{array}$} & Case A & $\begin{array}{l}\text { Proactive engagement, greater } \\
\text { community participation }\end{array}$ & $\begin{array}{l}\text { Community planting, mural } \\
\text { wall design, dialogue sessions, } \\
\text { volunteering information }\end{array}$ \\
\hline & Case B & $\begin{array}{l}\text { Buy-in of key stakeholders; } \\
\text { formal and informal } \\
\text { engagement; management of } \\
\text { public expectations; community } \\
\text { out-reach }\end{array}$ & $\begin{array}{l}\text { Onsite community planting; } \\
\text { Government's central } \\
\text { complaints unit (1823 Citizens } \\
\text { Easy Link (CEL)) }\end{array}$ \\
\hline \multirow[t]{2}{*}{$\begin{array}{l}\text { Community } \\
\text { benefits }\end{array}$} & Case A & $\begin{array}{l}\text { Provision of direct and indirect } \\
\text { benefits }\end{array}$ & $\begin{array}{l}\text { Low dust and noise generating } \\
\text { construction methods, free } \\
\text { house improvement services, } \\
\text { improved greenery around } \\
\text { construction site }\end{array}$ \\
\hline & Case B & $\begin{array}{l}\text { Buy-in of key stakeholders; } \\
\text { formal and informal } \\
\text { engagement; management of } \\
\text { public expectations; community } \\
\text { out-reach }\end{array}$ & Onsite community planting \\
\hline
\end{tabular}

For further progress to be made in stakeholder management, the Hong Kong real estate and construction industry needs to address:

- The reform of existing procurement systems to allow for more innovative and collaborative approaches to the development process.

- A change in culture throughout the industry to allow participants to focus on cooperation and collaboration rather than defensive reactions - the establishment of relationship management approaches throughout the industry.

- A focus on the real meaning of value in the project context rather than a decision-making process based on lowest initial costs.

- A commitment to community involvement and a full implementation of the principles of CSR in both public and private sectors.

- A refocusing on community benefit as a mechanism for assessing the performance of projects. 


\section{Acknowledgement}

The authors would like to acknowledge the contribution from the Research Grants Council, Hong Kong (Grant No. HKU712204E and HKU715807E) for the funding of this research.

\section{References}

Anvuur, A.M. (2008) Cooperation in Construction Projects: Concept, Antecedents and Strategies, PhD Thesis, The University of Hong Kong, Hong Kong.

Chan, D.W.M., Chan, A.P.C., Lam, P.T.I., Lam, E.W.M. and Wong, J.M.W. (2007) Evaluating guaranteed maximum price and target cost contracting strategies in Hong Kong construction industry. Journal of Financial Management of Property and Construction, 12(3):139-149.

Chan, K.Y.J. (2003) A challenging task - temporary traffic arrangement. Highways Department Newsletter, 54, p. 15e, available athttp://www.hyd.gov.hk/eng/public/publications/newsletter/Issue54/eng/e15.pdf (Accessed on 21 June 2008).

Cleland, D.I. and Ireland, L.R. (2007) Project Management: Strategic Design and Implementation (5th edn). New York: McGraw-Hill.

Donaldson, T. and Preston, L. (1995) The stakeholder theory of the corporation: concepts, evidence, and implications. Academy of Management Review, 20(1):65-91.

Haley, G. \& Shaw, G. (2002) Is 'guaranteed maximum price' the way to go? Hong Kong Engineer (Online Journal), January, available at http:/ / www.hkengineer.org.hk/program/home/articlelist.php?cat=business\&volid=19, accessed 10th September 2008.

Hong Kong Housing Authority (HKHA) (2005), Modified Guaranteed Maximum Price (MGMP) Contracting for the Public Rental Housing Development at Eastern Harbour Crossing Site Phase 4, available at http://news.apmhk.org.hk/_attachments/1277971/Partnering\%20SIG\%20\%20MGMP_EHC\%20SITE\%20PHASE_4.ppt (Accessed on 2 September 2008).

Lau, N. (2008) Backpay row brings traffic to standstill. The Standard. 10 January 2008 (Online newspaper), available at http://www.thestandard.com.hk/news_detail.asp?pp_cat=11\&art_id=59794 \&sid=17036540\&con_type=1\&d_str=20080110\&sear_year=2008, (Accessed 2 September 2008).

Mahesh, G., Kumaraswamy, M., Anvuur, A. and Coffey, V. (2007) Contracting for community development: a case study based perspective of a public sector client initiative in Hong Kong. Fourth International Conference on Construction in the 21st Century (CITC-IV) - Accelerating Innovation in Engineering, Management and Technology. Gold Coast, Australia, 11-13 July 2007.

Olander, S. (2007) Stakeholder impact analysis in construction project management. Construction Management and Economics, 25(3):277-287.

Rowlinson, S. (2009) Corporate social responsibility in the Hong Kong and Asia Pacific construction industry. In: Murray, M. and Dainty, A. (eds) Corporate Social Responsibility in the Construction Industry. Abingdon: Taylor and Francis, pp. 327-350.

Rowlinson, S. and Cheung, Y.K.F. (2008) Stakeholder management through empowerment: modelling project success. Construction Management and Economics, 26(6):611-623.

Thomas, R., Marosszeky, M., Karim, K., Davis, S. and McGeorge, D. (2002) The importance of project culture in achieving quality outcomes in construction. In: Formoso, C.T. and Ballard, G. (eds). Proceedings of the 10th Annual Conference on Lean Construction. Gramado, Brazil, August 2002.

Walker, D.H.T., Bourne, L. and Rowlinson, S. (2008) Stakeholders and the supply chain. In: Walker, D.H.T. and Rowlinson, S. (eds). Procurement System: A Cross-Industry Management Perspective. Abington: Taylor and Francis, pp. 70-100. 


\section{Author Queries}

\{AQ1\} The terms such as "The Client", "Viaduct Contractor", "Bridge Contractor", "Engineer's Representative", "Engineer's Representative", "The Engineer", "Government Departments", "Community Planting Exercise" are used inconsistently both in lower case and in caps. Please confirm whether we can leave this as author usage.

\{AQ2\} For emphasis words, author has given terms in italics as well in quotes. We have deleted quotes and retained only italics. Please confirm.

\{AQ3\} Please confirm the change made in the sentence "Some contractual provisions ... contractors' designs and the TMLG". 